This article was published in Applied Thermal Engineering, 65 (1-2), 273-281, 2014

http://dx.doi.org/10.1016/j.applthermaleng.2013.12.056

\title{
Impact of using cool paints on energy demand and thermal comfort of a residential building
}

\author{
Diana Dias ${ }^{\mathrm{a}, \mathrm{b}}$, João Machado ${ }^{\mathrm{b}}$, Vítor Leal ${ }^{\mathrm{c}}$, Adélio Mendes ${ }^{\mathrm{a},{ }^{*}}$ \\ a LEPAE, Departamento de Engenharia Química, Faculdade de Engenharia, Universidade do Porto, Rua \\ Dr. Roberto Frias, s/n, 4200-465 Porto, Portugal \\ ${ }^{b}$ CIN e Corporação Industrial do Norte, S.A., Avenida Dom Mendo, n. ${ }^{\circ} 831$, Apartado 1008, 4471-909 Maia, \\ Portugal \\ ' IDMEC, Departamento de Engenharia Mecânica, Faculdade de Engenharia, Universidade do Porto, Rua \\ Dr. Roberto Frias, s/n, 4200-465 Porto, Portugal
}

\begin{abstract}
This work studies the role of using cool paints and/or thermal insulation on the thermal behavior and energy demand of a residential building. Buildings with thermal characteristics representing both old and new constructions are considered; the results were obtained using the dynamic computer simulator ESP-r.

For a case-study building in Portugal, in the summer, it was found that an increase in roof and façade value of total solar reflectance from $50 \%$ to $92 \%$ reduces the maximum free-float indoor temperature between $2.0^{\circ} \mathrm{C}$ and $3.0^{\circ} \mathrm{C}$ in old construction (without thermal insulation), and between $1.2^{\circ} \mathrm{C}$ and $2.2^{\circ} \mathrm{C}$ in new construction (with thermal insulation). This has as a trade-off effect the decrease of the minimum indoor temperature of up to $1.5^{\circ} \mathrm{C}$. The results of annual energy demand for heating show a maximum penalization of about $30 \%$ when using cool paints. However, it was demonstrated that the cooling demand almost disappears, thus eliminating the need to install air- conditioning devices.

The analysis of two specific hot periods of real summer weather data shows that the sun's altitude is critical on which solution originates the highest temperature reduction.
\end{abstract}

\section{Introduction}

Since the 90s, the frequency and intensity of heat waves have increased [1] and weather events like these are expected to be more severe in the future [2]. These phenomena have a negative impact on human health, decreasing indoor-thermal comfort in buildings and thus increasing energy consumption.

The worldwide energy consumption, particularly to obtain indoor thermal comfort in 
buildings, has had a constant growth. In Europe, between 1990 and 2005, the absolute level of final household energy consumption rose by an average of $1.0 \%$ per year and, in 2005 , the residential sector accounted for $26.6 \%$ of the final energy consumption [3]. In Portugal, the fraction of energy for indoor thermal comfort already has a significant impact in global energy demand, approximately $22 \%$ of the energy used in residential buildings [4].

Until 2020, the European Union (EU) is committed to reduce energy use by $20 \%$, referred to 1990 [5]. To achieve this goal, the EU has imposed that all Member States must implement measures to apply minimum energy performance requirements for buildings and ensure the certification of building energy performance [6]. According to these guidelines, the Portuguese government decided to classify buildings according to their thermal efficiency [7-9].

One of the strategies that can be used to decrease energy consumption during the heating season is to coat buildings façades and roofs with special coatings called cool paints. There are two ways where cool paints may contribute to control the heat load of a building: reflecting the incident solar radiation and radiating the heat absorbed by emitting infrared (IR) radiation.

The reflectance is normally characterized by the so-called total solar reflectance index (TSR). The value of TSR is obtained by analyzing the reflectance over twenty specific wavelengths, which covers the solar spectrum [10].

The color of a paint film depends on its visible reflectance spectrum. However, increasing the IR reflectance of coatings, which accounts for almost $52 \%$ of the total solar radiation energy e see Fig. 1, it is possible to increase the solar radiation reflection without interfering with the surface color.

The so-called cool pigments can dramatically contribute to the TSR increase of paints, enhancing the reflectance of the IR radiation.

Most of the paints show very high emissivity values; for example, usual exterior paints show emissivity values in the range of 0.90 . It means that a paint film when heated radiates in the IR spectrum $90 \%$ of the energy that a black body would do. The emissivity is mostly not disturbed by the surface aging or cleanness.

In 1931, Paul Kubelka and Franz Munk published an article deriving a mathematical equation of the reflectance of achromatic paints as a function between the reflectance of the substrate and the coating thickness [12]. Later, in 1947, Kubelka determined the validation range of the Kubelka-Munk theory and developed new formulas more adapted for practical use [13]. More recently, a great deal of research concerning the development and the use of cool paints has been conducted by the Lawrence Berkeley National Laboratory (LBNL). Akbari [14] studied the impact of a cool roof real application on the energy savings and comfort performance in two small non-residential buildings, located in Nevada. This author showed energy savings and drop of temperature in the summer. Levinson et al. [15] identified and characterized 87 pigments with cool properties, which allowed LBNL to create a pigment database that has free access [16]. In addition, Levinson et al. [17] assessed the effect of soiling and cleaning (wiping, rinsing, washing and bleaching) on the value of the reflectance of the roof coating samples. These authors concluded that wiping restores some of the initial reflectance, but rinsing and/or washing are more effective and bleaching does not greatly increase the solar reflectance of a washed roof. The same workgroup also assessed the solar reflectance variation over three-year weathering tests on asphalt shingles, located 
in Berkeley, California, and in Houston, Texas. Berdahl et al. [18] observed that after this period of time changes in solar reflectance were small. Researchers from the LBNL also described methods for creating solar-reflective surfaces. First in 2007, Levinson et al. [19] presented how to create non-white surfaces and their application to a wide variety of residential roofing materials, including metal, clay tile, concrete tile, wood and asphalt shingle and, in 2010, Levinson et al. [20] created a prototype with the demonstration of a new process for coating concrete tile and asphalt shingle roofing products that uses a two-layer spray coating.

Other authors made similar studies, for example, Ichinose et al. [21] performed an interesting study about the paint performance over time with respect to surface contamination and degradation of reflectivity throughout environmental exposure tests. This study demonstrates that panels that were coated with high-reflectivity paint can preserve thermal conditioning effects longer than the conventional ones. Romeo and Zinzi [22] also studied the impact of a cool roof real application on the energy and comfort performance in an existing non-residential building located on the west coast of Sicily. The effect of cool coatings in mitigating the thermal conditions was demonstrated and an average reduction of $2.3{ }^{\circ} \mathrm{C}$ of the operative temperature, during the cooling season, was observed. This study also recorded a $54 \%$ reduction of the cooling energy demand.

Moreover, studies of cool roof performance have been carried out by computer simulation. Building simulation helps not only to predict indoor thermal behavior of buildings and their energy consumption (annual cooling and heating load), but also to develop environmentally-friendly design options. Luxmoore et al. [23] used a dynamic and detailed energy simulation tool, DEROB-LTH, to create recommendation actions and strategies to mitigate temperature increase in residential buildings in Queensland, Australia. These authors concluded that the heat island impacts can be mitigated through the use of light colored or high albedo surfaces (roofs, walls, roads and other paved areas). Also Wang et al. [24] used a dynamic thermal simulation software, EDSL Tas, to assess a retail shed, located in six different locations around the world, and with external surfaces painted with reflective coatings. These authors prove that the use of solar reflective coatings is effective in reducing cooling loads and overall electricity consumption, in particular in hot climates. Han et al. [25] developed a mathematical model to assess the energy performance of different colored roof structures. These authors showed cooling load reductions of up to $9.3 \%$ when the roof color changes from black (solar reflectance value of $15 \%$ ) to white (solar reflectance value of $52 \%$ ). The study of the energy performance of existing or projected buildings has been growing over the years. More recently, however, the thermal comfort of buildings in future weather scenarios has been considered using simulation tools [27].

In this work, the application of cool paints on a building was assessed using an open source simulator, ESP-r [26]. ESP-r is an integrated energy modeling tool for the simulation of the thermal, visual and acoustic performance of buildings and the evaluation of their energy use associated with environmental control systems.

This paper focuses mainly on assessing the impact of cool paints and/or thermal insulation on the thermal behavior and energy demand of a residential building. Buildings with different thermal characteristics (representing both old and new constructions) and with cool paints applied both on the roof and façade surfaces are assessed. The assumptions made concerning the thermal comfort of the various 
buildings, operational details and reference TSR of the buildings are all based on the Portuguese legislation. This study can provide recommendations for house-owners in terms of deciding for one or another thermal comfort solution and is of particular relevance for the renovation of old houses. Indeed, especially in this case, the use of either of these two thermal comfort solutions has not only different outputs but also very different costs.

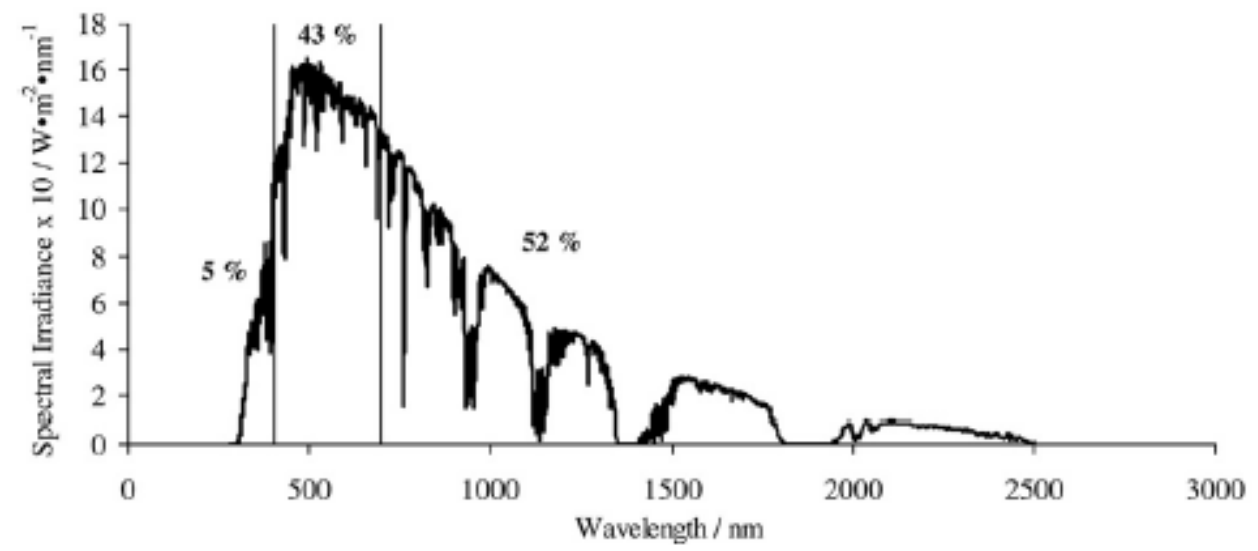

Fig. 1. Terrestrial global spectrum, AM 1,5, $1000 \mathrm{~W} \mathrm{~m}^{-2}$ - based on ASTM G173-03 [11].

\section{Simulation}

In this work, a single villa was modeled on a yearly basis; it had two floors and a partially inhabited attic, as indicated in Fig. 2. The ground floor has a living room (LR), a dining room (DR), a kitchen (KT), a toilet (TL), a hall (HL) and stairs (ST). The first floor has three bedrooms (BD), a suite (SU), a TL, a bathroom (BR), a corridor (CR) and ST. The attic has two parts which are inhabited, a playroom (PL) and ST. Although the building was made of all these zones, only some of them were considered to obtain the average indoor temperature per floor. The zones considered were the LR, DR and the KT on the ground floor, the three BD and the SU on the first floor and the PL in the attic.

According to the Portuguese law [9], a constant value of 0.6 air changes per hour was considered. The internal gains of the zones considered in the calculation of the indoor temperature were settled to $4 \mathrm{~W} \mathrm{~m}^{-2}$, also accordingly to the Portuguese law [9]; in the remaining zones, it was assumed to have $1 \mathrm{~W} \mathrm{~m}^{-2}$ of internal gains (except for the two inhabited zones in the attic that were assumed to have no internal gains).

The building has a total area of $26.3 \mathrm{~m}^{2}$ of windows with clear glass. It was taken into account the seasons and the existence of venetian blinds on windows. These venetian blinds were simulated as an additional layer over the windows, without any control system. Between June and September, the venation blinds cover $75 \%$ of each window, while during the rest of the year it was assumed $50 \%$ of coverage.

The dynamic thermal behavior and energy demand of this residential building were simulated using ESP-r [26]. Simulations of a full year were performed, but for the thermal behavior discussion only two specific periods were selected: one typical summer and one typical winter weeks as recommended by the simulator. According to the manual of ESP-r simulator, typical weeks are determined taking into account the average and total heating and cooling degree days and solar radiation data. These values are compared with the seasonal values and the weeks with the least deviation (applying 
user supplied weighting factors [28]) are reported.

Two different simulations were performed: a free-float simulation to evaluate the indoor temperature over the year and a simulation to assess the energy demand needed to keep the inside temperature within the recommended range, between $20^{\circ} \mathrm{C}$ and $25^{\circ} \mathrm{C}$ [9]. Two old constructions, without thermal insulation, were studied: i) a single wall façade (named BD1) and ii) a double wall façade (named BD2). A modern building, with a single wall façade with thermal insulation (named BD3), was also studied. The buildings were placed in three different cities of Portugal, in the north, center and south (Porto, $41^{\circ} 9^{\prime} \mathrm{N} 8^{\circ} 36^{\prime} \mathrm{W}$; Lisbon, $38^{\circ} 43^{\prime} \mathrm{N} 9^{\circ} 8^{\prime} \mathrm{W}$ and; Faro, 3702' $\mathrm{N} 7^{\circ} 55^{\prime} \mathrm{W}$, respectively), to cover a wide range of moderate climates. The weather data of these three locations were obtained from the website of the Energy Efficiency and Renewable Energy [29].

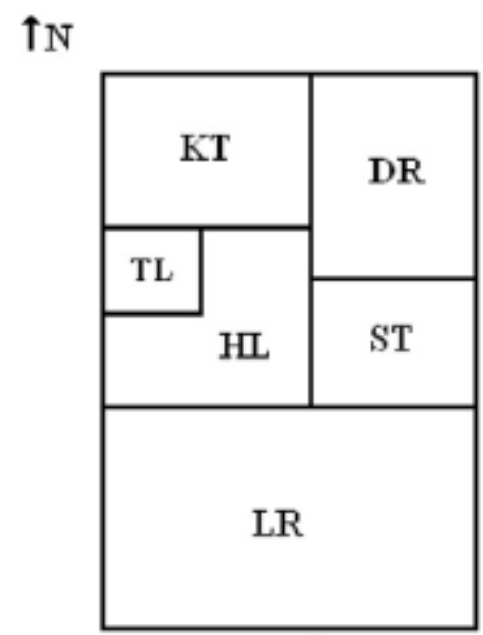

a)

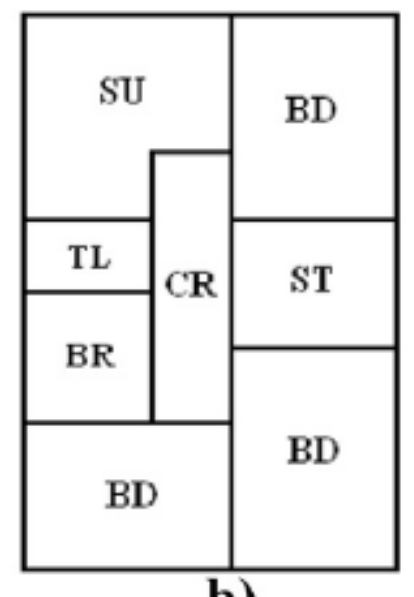

b)

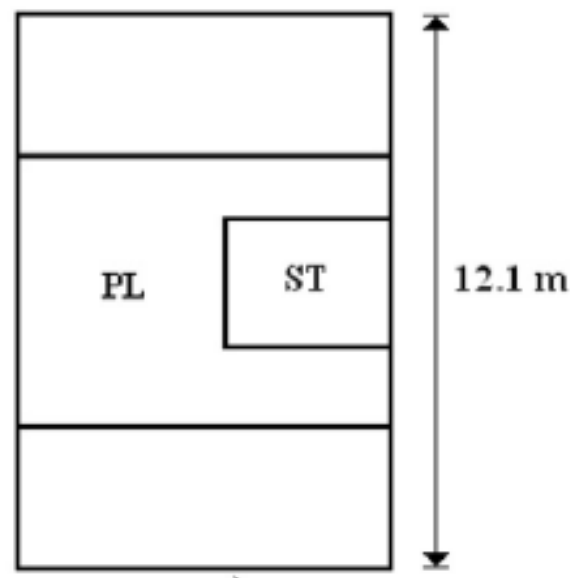

c)

Fig. 2. Plant of the building: a) ground floor, b) first floor and c) attic.

\subsection{Building 1 e single wall}

Building 1 (BD1) is a single wall building (building whose exterior walls had masonry composed by a single dense layer e the brick layer). This building has no thermal insulation, neither on the façades (external walls) nor on the roof (roof slab). The construction details of BD1 are given in Table 1, where all layers that compose the construction are described, from the exterior to the interior. These construction details and the specifications of each layer (e.g. conductivity, density, specific heat, emissivity and absorption) follow the recommendations of the national legislation [30].

Two different studies were performed for BD1: i) the impact of using cool paints, both on roof and façade surfaces, named BD1-CP, and ii) the impact of using thermal insulation, named BD1-TI.

In BD1-CP, the cool paint was assumed to have $92 \%$ of TSR and 0.90 of emissivity, which correspond to experimental values obtained for a high quality white exterior paint.

BD1-TI was assessed assuming the use of $60 \mathrm{~mm}$ of expanded polystyrene (EPS) insulation, both on external walls and on the roof slab, as shown in Table 2. The conductivity value of this insulation material was considered to be $0.042 \mathrm{~W} \mathrm{~m}^{-1} \mathrm{~K}^{-1}$. 
Table 1. Construction details of the building with a single wall façade (BD1)

\begin{tabular}{llcl}
\hline Construction & Layer & Thickness $/ \mathrm{mm}$ & $\mathrm{U} / \mathrm{W} \mathrm{m}^{-2} \mathrm{~K}^{-1}$ \\
\hline External wall & Coating & 0.2 & 1.3 \\
& Plaster & 30 & \\
& Brick & 190 & \\
Internal wall & Plaster & 10 & 2.1 \\
& Plaster & 10 & \\
& Brick & 110 & 0.7 \\
Ground floor & Plaster & 10 & \\
& Common earth & 300 & \\
& Gravel & 300 & \\
& Concrete & 300 & 5.6 \\
Window & Asphalt & 10 & 2.0 \\
Slab & Concrete & 20 & \\
& Wood floor & 20 & 1.6 \\
Roof slab & Clear glass & 8 & \\
& Plaster & 10 & \\
& Concrete & 240 & \\
& Plaster & 10 & \\
& Clay tile & 5 & \\
& Air & 3 & \\
& Plaster & 5 & \\
& Brick & 110 & \\
& Plaster & 5 & \\
\hline
\end{tabular}

Table 2. Construction details of BD1-T1 - in bold the differences from BD1

\begin{tabular}{llcl}
\hline Construction & Layer & Thickness $/ \mathrm{mm}$ & $U / \mathrm{W} \mathrm{m}^{-2} \mathrm{~K}^{-1}$ \\
\hline External wall & Coating & 0.2 & $\mathbf{0 . 5}$ \\
& Plaster & 30 & \\
& Insulation & $\mathbf{6 0}$ & \\
& Brick & 190 & \\
Roof slab & Plaster & 10 & $\mathbf{0 . 5}$ \\
& Clay tile & 5 & \\
& Air & 3 & \\
& Plaster & 5 & \\
& Insulation & $\mathbf{6 0}$ & \\
& Brick & 110 & \\
& Plaster & 5 & \\
\hline
\end{tabular}

\subsection{Building 2 e double wall}

Building 2 (BD2) has a double wall façade. BD2 has no thermal insulation either on the façades (external walls) or on the roof (roof slab). The construction details of BD2 and the specifications of each layer (e.g. conductivity, density, specific heat, emissivity and absorption) also follow the recommendations of the national legislation [30]. Differences on construction details are indicated in bold in Table 3.

Similarly to the previous case, two different studies were performed: i) the impact of using cool paints, both on roof and façade surfaces, named BD2-CP, and ii) the impact of using thermal insulation, named BD2-TI.

Cool paints having also $92 \%$ of TSR and 0.90 of emissivity were considered for BD2-CP. BD2-TI was assessed also assuming $60 \mathrm{~mm}$ of EPS insulation (conductivity of $0.042 \mathrm{~W}$ $\mathrm{m}^{-1} \mathrm{~K}^{-1}$ ), both on external walls and on the roof slab, as shown in Table 4. 
Table 3. Construction details of the double wall façade building (BD2) - differences from BD1 highlighted in bold.

\begin{tabular}{llcl}
\hline Construction & Layer & Thickness $/ \mathrm{mm}$ & $\mathrm{U} / \mathrm{W} \mathrm{m} \mathrm{m}^{-2} \mathrm{~K}^{-1}$ \\
\hline External wall & Coating & 0.2 & $\mathbf{1 . 0}$ \\
& Plaster & 30 & \\
& Brick & $\mathbf{1 1 0}$ & \\
& Air & $\mathbf{6 0}$ & \\
& Brick & $\mathbf{1 1 0}$ & 2.8 \\
Window & Plaster & 10 & \\
& Clear glass & 8 & \\
& Air & $\mathbf{1 6}$ & \\
& Clear glass & $\mathbf{5}$ & \\
& & & \\
\end{tabular}

Table 4. Construction details of BD2-TI, where differences from BD2 are highlighted in bold.

\begin{tabular}{llcl}
\hline Construction & Layer & Thickness $/ \mathrm{mm}$ & $U / \mathrm{W} \mathrm{m} \mathrm{m}^{-2} \mathrm{~K}^{-1}$ \\
\hline External wall & Coating & 0.2 & $\mathbf{0 . 4}$ \\
& Plaster & 30 & \\
& Insulation & $\mathbf{6 0}$ & \\
& Brick & 110 & \\
& Air & 60 & \\
Roof slab & Brick & 110 & $\mathbf{0 . 5}$ \\
& Plaster & 10 & \\
& Clay tile & 5 & \\
& Air & 3 & \\
& Plaster & 5 & \\
& Insulation & $\mathbf{6 0}$ & \\
& Brick & 110 & \\
& Plaster & 5 & \\
\hline
\end{tabular}

\subsection{Building 3 e single wall with thermal insulation}

Building 3 (BD3) followed the present Portuguese laws [9] concerning the overall heat transfer coefficients. BD3 is a single wall building. This building has thermal insulation both on external walls and on the roof slab e construction details given in Table 5 . The construction details of BD3 and the specifications of each layer (e.g. conductivity, density, specific heat, emissivity and absorption) also follow the recommendations of the national legislation [30].

As BD3 already considers thermal insulation, so the impact of using cool paints, both on roof and façade surfaces were only assessed, named BD3-CP. Values of TSR and emissivity of cool paints were $92 \%$ and 0.90 respectively, as before. 
Table 5. Construction details of BD3.

\begin{tabular}{llcl}
\hline Construction & Layer & Thickness $/ \mathrm{mm}$ & $\mathrm{U} / \mathrm{W} \mathrm{m} \mathrm{m}^{-2} \mathrm{~K}^{-1}$ \\
\hline External wall & Coating & 0.2 & 0.5 \\
& Plaster & 30 & \\
& Insulation & 60 & \\
& Brick & 190 & \\
Ground floor & Plaster & 10 & 0.5 \\
& Common earth & 300 & \\
& Gravel & 300 & \\
& Concrete & 300 & \\
& Asphalt & 200 & 2.8 \\
Window & Concrete & 200 & \\
& Wood floor & 20 & \\
& Clear glass & 8 & \\
& Air & 16 & \\
& Clear glass & 5 & \\
& Clay tile & 5 & \\
& Plaster & 10 & \\
& Insulation & 60 & \\
& Brick & 110 & \\
& Plaster & 10 & \\
\hline
\end{tabular}

\section{Results and discussion}

\subsection{Porto, Portugal}

In Porto, the typical weeks considered were from June 26th to July 2nd and from January 22nd to 28th. Based on typical colors of the buildings and according to the Portuguese legislation [9], the façades of the reference case in Porto were assumed to have $50 \%$ of TSR. The emissivity assumed a value of 0.90 . The roof was assumed to have $40 \%$ of TSR and 0.90 of emissivity (clay tile).

Results of buildings thermal performance are presented in Tables 6 and 7, related to the typical summer week and the typical winter week, respectively. In these tables, $T_{\max }$ is the week average daily maximum temperature and $T_{\min }$ is the week average daily minimum temperature. The indoor temperatures of the ground floor, first floor and second floor were separately determined as well as the exterior temperature of the building.

Summer results show that the thermal impact of cool paints is more significant on the second floor, followed by the first floor and finally the ground floor. Since the second floor has a larger exposed area to solar radiation, in BD1 the cool paints can promote a higher cooling effect, $3.0^{\circ} \mathrm{C}$ on $\mathrm{T}_{\max }$. On the ground floor the cooling effect was smaller, $2.1^{\circ} \mathrm{C}$.

In the typical winter week, BD1-CP shows a non-desirable reduction of $\mathrm{T}_{\min }$ between 0.8 ${ }^{\circ} \mathrm{C}$ and $1.4{ }^{\circ} \mathrm{C}$. Since cool paints are related to radiation control and the level of radiation in winter is expected to be low, these values show otherwise. Indeed, Fig. 3 shows the daily direct solar radiation for both typical weeks; the winter irradiation is just $38 \%$ smaller than the summer irradiation.

Table 8 shows annual cooling and heating demand of Porto. For BD1-CP, although the annual energy demand had a heating load penalization of about 2.9 $\mathrm{MWh}^{-1}$, it was 
demonstrated that the cooling demand almost disappears, i.e. the building was comfortable even during the peak summer without mechanical cooling.

In the typical winter week, it was found that BD1-TI led to an increase between $0.7{ }^{\circ} \mathrm{C}$ and $2.1^{\circ} \mathrm{C}$ on $\mathrm{T}_{\min }$. On the other hand, in the typical summer week, one can see that on the ground floor there was a reduction of $0.4{ }^{\circ} \mathrm{C}$ on $\mathrm{T}_{\max }$, while on the first and second floors there was a temperature increase of $0.4{ }^{\circ} \mathrm{C}$. The temperature reduction on the ground floor is due to the thermal inertia of the ground (soil), which leads to a lower ground temperature compared to the exterior air temperature. Therefore, the use of thermal insulation helped to keep or to reduce the indoor temperature of the ground floor. Table 8 shows that these temperature variations had an impact on the energy demand of BD1-TI: a very significant reduction of the cooling demand was observed,

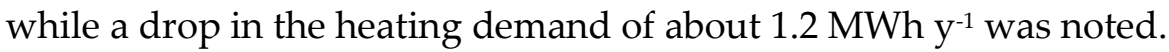

In order to perform a comparison of thermal insulation (BD1-TI) with the other two previous cases (reference case e BD1 e and cool paints e BD1-CP), Fig. 4 shows the hourly temperature history over the typical summer week. The exterior air temperature history is also presented.

Although the use of thermal insulation had the greatest reduction on the impact of exterior air temperature variations, decreasing the indoor temperature range, BD1-TI exhibited, most of the time, the highest indoor temperature. On the other hand, cool paints led to a permanent and significant reduction in the indoor temperature.

It should also be noted that simulations with BD1-CP and BD1-TI having double glazed windows were performed; however results showed that the use of double glazed windows have no significant impact.

Results of BD2-CP are similar to those obtained for BD1-CP. The typical summer week showed a $\mathrm{T}_{\max }$ reduction between $2.0^{\circ} \mathrm{C}$ and $3.0^{\circ} \mathrm{C}$ and in the typical winter week a drop between $0.8^{\circ} \mathrm{C}$ and $1.5^{\circ} \mathrm{C}$ on Tmin was observed. Table 8 shows that also in this case the cooling demand almost disappeared and the annual heating demand had an increase of about 2.8 $\mathrm{MWh} \mathrm{y}^{-1}$.

For BD2-TI, in the typical winter week, an increase between $0.6^{\circ} \mathrm{C}$ and $2.7^{\circ} \mathrm{C}$ on $\mathrm{T}_{\min }$ was observed. In the typical summer week occurred a slight reduction of $0.2{ }^{\circ} \mathrm{C}$ of $\mathrm{T}_{\max }$ on the ground floor and an increase of $0.8^{\circ} \mathrm{C}$ on each of the other floors. In Table 8, one can see

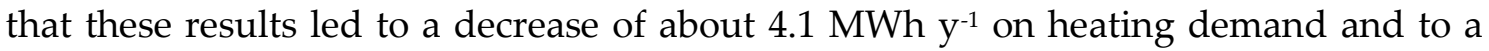
small raise of the annual cooling demand of BD2-TI.

In the typical summer week, BD3-CP exhibited a $\mathrm{T}_{\max }$ decrease between $1.2{ }^{\circ} \mathrm{C}$ and $2.2{ }^{\circ} \mathrm{C}$ and, in the typical winter week, a maximum reduction in $\mathrm{T}_{\min }$ of $1.1^{\circ} \mathrm{C}$ was observed.

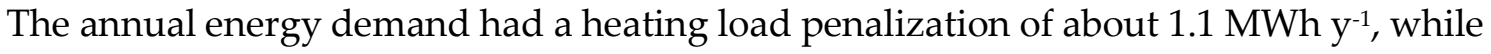
it was demonstrated that cooling demand almost vanishes. 
Table 6. $T_{\max }$ over the typical summer week of Porto

\begin{tabular}{|c|c|c|c|c|c|c|}
\hline Building & Case & Temperature $/{ }^{\circ} \mathrm{C}$ & $\begin{array}{l}\text { Ground } \\
\text { floor }\end{array}$ & $\begin{array}{l}\text { First } \\
\text { floor }\end{array}$ & $\begin{array}{l}\text { Second } \\
\text { floor }\end{array}$ & Exterior \\
\hline \multirow[t]{5}{*}{ BD1 } & Reference & $T_{\max }$ & 22.0 & 23.2 & 23.2 & 23.2 \\
\hline & Cool paints & $T_{\max }$ & 19.9 & 20.7 & 20.2 & \\
\hline & (BD1-CP) & $\Delta T_{\max }$ & -2.1 & -2.5 & -3.0 & - \\
\hline & Insulation & $T_{\max }$ & 21.6 & 23.6 & 23.6 & 23.2 \\
\hline & (BD1-TI) & $\Delta T_{\max }$ & -0.4 & +0.4 & +0.4 & - \\
\hline \multirow[t]{5}{*}{ BD2 } & Reference & $T_{\max }$ & 22.0 & 23.5 & 23.3 & 23.2 \\
\hline & Cool paints & $T_{\max }$ & 20.0 & 21.0 & 20.3 & \\
\hline & (BD2-CP) & $\Delta T_{\max }$ & -2.0 & -2.5 & -3.0 & - \\
\hline & Insulation & $T_{\max }$ & 21.8 & 24.3 & 24.1 & 23.2 \\
\hline & (BD2-TI) & $\Delta T_{\max }$ & -0.2 & +0.8 & +0.8 & - \\
\hline \multirow[t]{3}{*}{ BD3 } & Reference & $T_{\max }$ & 22.2 & 24.3 & 24.1 & 23.2 \\
\hline & Cool paints & $T_{\max }$ & 21.0 & 22.5 & 21.9 & \\
\hline & (BD3-CP) & $\Delta T_{\max }$ & -1.2 & -1.8 & -2.2 & - \\
\hline
\end{tabular}

Table 7. $T_{\min }$ over the typical winter week of Porto

\begin{tabular}{|c|c|c|c|c|c|c|}
\hline Building & Case & Temperature $/{ }^{\circ} \mathrm{C}$ & $\begin{array}{l}\text { Ground } \\
\text { floor }\end{array}$ & $\begin{array}{l}\text { First } \\
\text { floor }\end{array}$ & $\begin{array}{l}\text { Second } \\
\text { floor }\end{array}$ & Exterior \\
\hline \multirow[t]{5}{*}{ BD1 } & Reference & $T_{\min }$ & 9.5 & 10.6 & 9.1 & 4.8 \\
\hline & Cool paints & $T_{\min }$ & 8.7 & 9.2 & 8.2 & \\
\hline & (BD1-CP) & $\Delta T_{\min }$ & -0.8 & -1.4 & -0.9 & - \\
\hline & Insulation & $T_{\min }$ & 10.2 & 11.8 & 11.2 & 4.8 \\
\hline & (BD1-TI) & $\Delta T_{\min }$ & +0.7 & +1.2 & +2.1 & - \\
\hline \multirow[t]{5}{*}{ BD2 } & Reference & $T_{\min }$ & 10.1 & 11.5 & 9.5 & 4.8 \\
\hline & Cool paints & $T_{\min }$ & 9.3 & 10.0 & 8.5 & \\
\hline & $(\mathrm{BD} 2-\mathrm{CP})$ & $\Delta T_{\min }$ & -0.8 & -1.5 & -1.0 & - \\
\hline & Insulation & $T_{\min }$ & 10.7 & 13.0 & 12.2 & 4.8 \\
\hline & (BD2-TI) & $\Delta T_{\min }$ & +0.6 & +1.5 & +2.7 & - \\
\hline \multirow[t]{3}{*}{ BD3 } & Reference & $T_{\min }$ & 10.8 & 12.6 & 11.9 & 4.8 \\
\hline & Cool paints & $T_{\min }$ & 10.3 & 11.5 & 11.2 & \\
\hline & (BD3-CP) & $\Delta T_{\min }$ & -0.5 & -1.1 & -0.7 & - \\
\hline
\end{tabular}

Table 8. Annual energy demand for studied cases, located in Porto

\begin{tabular}{llllr}
\hline Building & Case & \multicolumn{2}{l}{ Energy demand/MWh $\mathrm{y}^{-1}$} \\
\cline { 3 - 5 } & & Cooling & Heating & Total \\
\hline BD1 & Reference & 0.4 & 11.2 & 11.6 \\
& Cool paints (BD1-CP) & $\approx 0$ & 14.1 & 14.1 \\
& Insulation (BD1-TI) & 0.3 & 10.0 & 10.3 \\
BD2 & Reference & 0.4 & 8.9 & 9.3 \\
& Cool paints (BD2-CP) & $\approx 0$ & 11.7 & 11.7 \\
& Insulation (BD2-TI) & 0.4 & 4.8 & 5.2 \\
BD3 & Reference & 0.4 & 4.8 & 5.2 \\
& Cool paints (BD3-CP) & $\approx 0$ & 6.0 & 6.0 \\
\hline
\end{tabular}




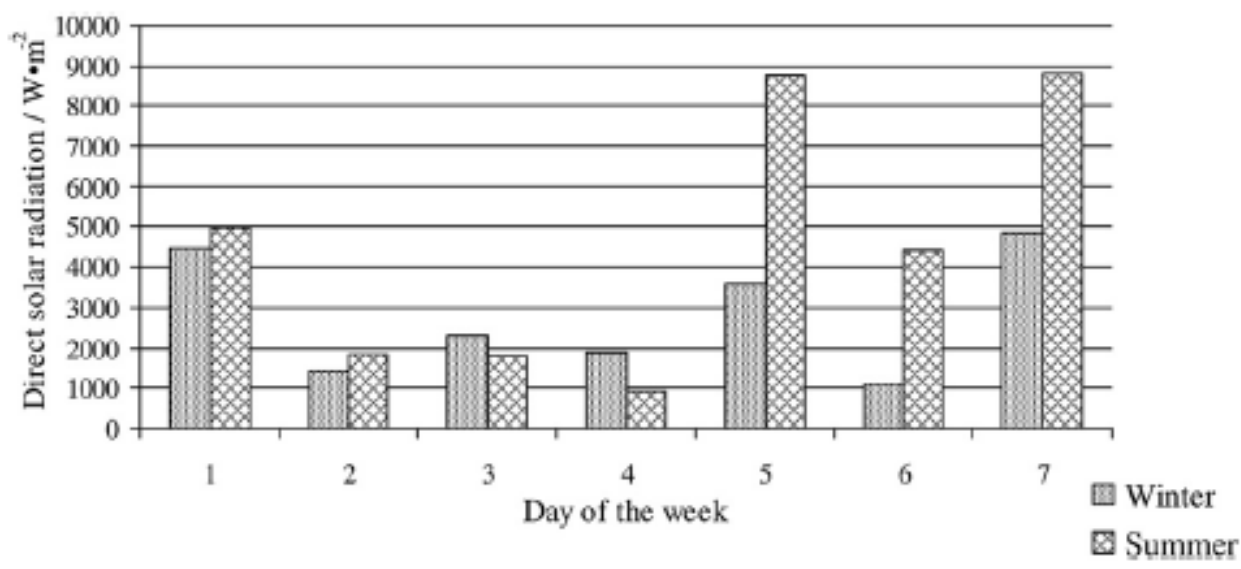

Fig. 3. Daily direct solar radiation over the typical weeks.

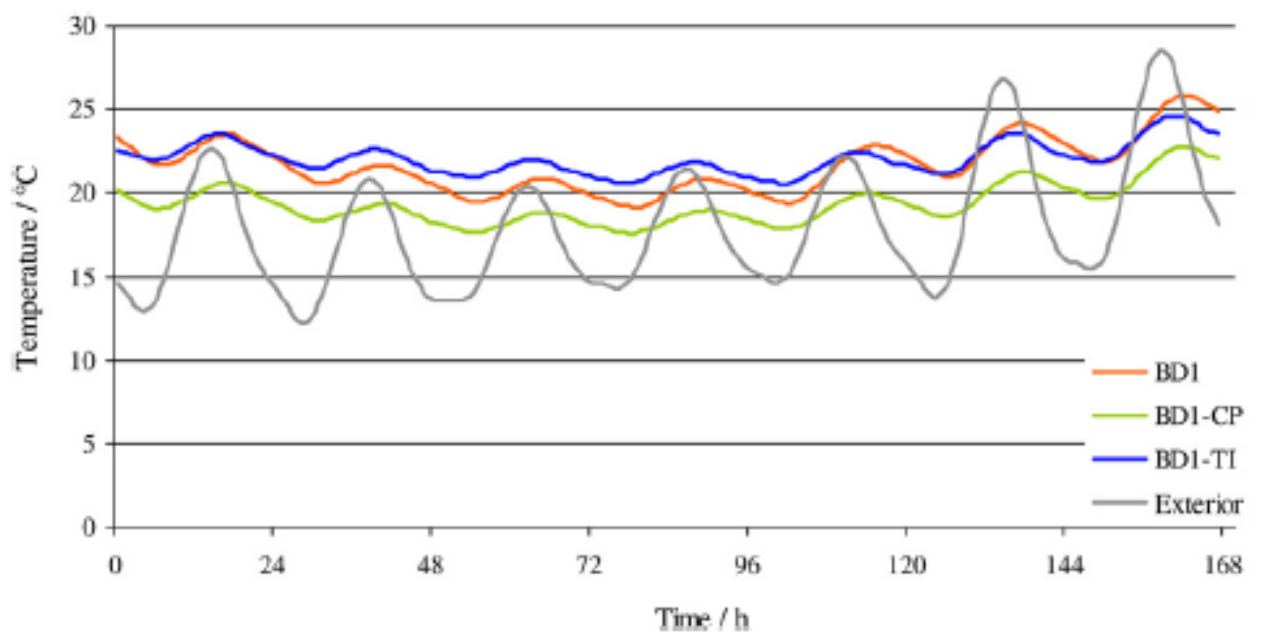

Fig. 4. Hourly temperature history, over typical summer week, for a single wall façade building.

\subsection{Lisbon, Portugal}

A similar study was performed for buildings located in Lisbon that is ca. $300 \mathrm{~km}$ south of Porto. In Lisbon, based on typical colors of the buildings and according to the Portuguese legislation [9], the TSR of the external wall coating was assumed to be $60 \%$ for the reference case. The roof was assumed to be clay tile, having $40 \%$ of TSR and 0.90 of emissivity.

Table 9 shows the average daily maximum temperature e $T_{\max }$ e over the typical summer week of Lisbon and Table 10 exhibits the average daily minimum temperature e $\mathrm{T}_{\min } \mathrm{e}$ over the typical winter week. In Lisbon, the typical weeks considered were from July 3rd to 9 th and from January 8 th to 14 th.

During the typical summer weeks, the use of cool paints played a more significant role in obtaining thermal comfort in Lisbon than in Porto. Table 9 shows that, in BD1-CP T $\max$ decreased between $2.4{ }^{\circ} \mathrm{C}$ and $4.6{ }^{\circ} \mathrm{C}$, while in BD2-CP it was observed a minimum reduction of $2.0^{\circ} \mathrm{C}$ on the ground floor and a maximum drop of $4.7^{\circ} \mathrm{C}$ on the second floor. In BD3-CP, cool paints represented a maximum decrease in $\mathrm{T}_{\max }$ of $2.9^{\circ} \mathrm{C}$.

On the other hand, the use of thermal insulation in buildings with old constructions types (BD1-TI and BD2-TI) led to a maximum $\mathrm{T}_{\max }$ decrease of $0.4{ }^{\circ} \mathrm{C}$ and a maximum 
rise of $0.9^{\circ} \mathrm{C}$ e see also Table 9 .

Table 10 shows that, during the typical winter week, cool paints had a significant impact reducing $\mathrm{T}_{\mathrm{min}}$ : a maximum temperature reduction of $1.3{ }^{\circ} \mathrm{C}$ was observed. In contrast, using thermal insulation $\mathrm{T}_{\min }$ increased between $0.8^{\circ} \mathrm{C}$ and $3.1^{\circ} \mathrm{C}$.

The consequences of these temperature variations on the annual energy demand of the building are shown in Table 11. In Lisbon, cool paints represented a maximum reduction on cooling demand of about 1.2 $\mathrm{MWh} \mathrm{y}^{-1}$ (BD1-CP and BD2-CP) and a maximum heating loads penalization of about $31 \%$ (BD2-CP). In the winter, the use of thermal insulation

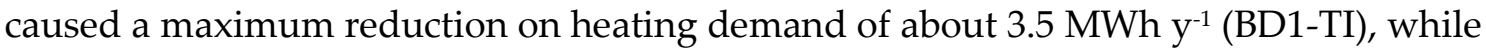
in summer it had no significant impact on cooling demand values.

Table 9. T $\max$ Over the typical summer week of Lisbon.

\begin{tabular}{|c|c|c|c|c|c|c|}
\hline Building & Case & Temperature $/{ }^{\circ} \mathrm{C}$ & $\begin{array}{l}\text { Ground } \\
\text { floor }\end{array}$ & $\begin{array}{l}\text { First } \\
\text { floor }\end{array}$ & $\begin{array}{l}\text { Second } \\
\text { floor }\end{array}$ & Exterior \\
\hline \multirow[t]{5}{*}{ BD1 } & Reference & $T_{\max }$ & 26.4 & 27.7 & 28.7 & 28.2 \\
\hline & Cool paints & $T_{\max }$ & 24.0 & 24.7 & 24.1 & \\
\hline & (BD1-CP) & $\Delta T_{\max }$ & -2.4 & -3.0 & -4.6 & - \\
\hline & Insulation & $T_{\max }$ & 26.0 & 28.0 & 28.6 & 28.2 \\
\hline & (BD1-TI) & $\Delta T_{\max }$ & -0.4 & +0.3 & -0.1 & - \\
\hline \multirow[t]{5}{*}{ BD2 } & Reference & $T_{\max }$ & 26.2 & 27.9 & 28.9 & 28.2 \\
\hline & Cool paints & $T_{\max }$ & 24.2 & 25.1 & 24.2 & \\
\hline & (BD2-CP) & $\Delta T_{\max }$ & -2.0 & -2.8 & -4.7 & - \\
\hline & Insulation & $T_{\max }$ & 26.1 & 28.8 & 29.3 & 28.2 \\
\hline & (BD2-TI) & $\Delta T_{\max }$ & -0.1 & +0.9 & +0.4 & - \\
\hline \multirow[t]{3}{*}{ BD3 } & Reference & $T_{\max }$ & 26.1 & 28.7 & 29.2 & 28.2 \\
\hline & Cool paints & $T_{\max }$ & 24.8 & 26.8 & 26.3 & \\
\hline & (BD3-CP) & $\Delta T_{\max }$ & -1.3 & -1.9 & -2.9 & - \\
\hline
\end{tabular}

Table 10. $\mathrm{T}_{\min }$ over the typical winter week of Lisbon.

\begin{tabular}{|c|c|c|c|c|c|c|}
\hline Building & Case & Temperature $/{ }^{\circ} \mathrm{C}$ & $\begin{array}{l}\text { Ground } \\
\text { floor }\end{array}$ & $\begin{array}{l}\text { First } \\
\text { floor }\end{array}$ & $\begin{array}{l}\text { Second } \\
\text { floor }\end{array}$ & Exterior \\
\hline \multirow[t]{5}{*}{ BD1 } & Reference & $T_{\min }$ & 12.1 & 13.4 & 11.9 & 8.1 \\
\hline & Cool paints & $T_{\min }$ & 11.5 & 12.2 & 11.1 & \\
\hline & (BD1-CP) & $\Delta T_{\min }$ & -0.6 & -1.2 & -0.8 & - \\
\hline & Insulation & $T_{\min }$ & 13.0 & 15.0 & 14.3 & 8.1 \\
\hline & (BD1-TI) & $\Delta T_{\min }$ & +0.9 & +1.6 & +2.4 & - \\
\hline \multirow[t]{5}{*}{ BD2 } & Reference & $T_{\min }$ & 12.8 & 14.3 & 12.4 & 8.1 \\
\hline & Cool paints & $T_{\min }$ & 12.0 & 13.0 & 11.5 & \\
\hline & (BD2-CP) & $\Delta T_{\min }$ & -0.8 & -1.3 & -0.9 & - \\
\hline & Insulation & $T_{\min }$ & 13.6 & 16.2 & 15.5 & 8.1 \\
\hline & (BD2-TI) & $\Delta T_{\min }$ & +0.8 & +1.9 & +3.1 & - \\
\hline \multirow[t]{3}{*}{ BD3 } & Reference & $T_{\min }$ & 13.8 & 15.7 & 15.1 & 8.1 \\
\hline & Cool paints & $T_{\min }$ & 13.2 & 14.9 & 14.5 & \\
\hline & (BD3-CP) & $\Delta T_{\min }$ & -0.6 & -0.8 & -0.6 & - \\
\hline
\end{tabular}


Table 11. Annual energy demand for studied cases, located in Lisbon.

\begin{tabular}{llllr}
\hline Building & Case & \multicolumn{3}{l}{ Energy demand/MWh y } \\
\cline { 3 - 5 } & & Cooling & Heating & Total \\
\hline \multirow{2}{*}{ BD1 } & Reference & 1.6 & 7.4 & 9.0 \\
& Cool paints (BD1-CP) & 0.4 & 9.6 & 10.0 \\
& Insulation (BD1-TI) & 1.4 & 3.9 & 5.3 \\
BD2 & Reference & 1.6 & 5.7 & 7.3 \\
& Cool paints (BD2-CP) & 0.4 & 7.5 & 7.9 \\
& Insulation (BD2-TI) & 1.6 & 2.7 & 4.3 \\
BD3 & Reference & 1.7 & 2.8 & 4.5 \\
& Cool paints (BD3-CP) & 0.8 & 3.5 & 4.3 \\
\hline
\end{tabular}

\subsection{Faro, Portugal}

An equivalent study was performed in Faro, Portugal; Faro is the southernmost city in Portugal and it is located ca. $500 \mathrm{~km}$ south of Porto and $200 \mathrm{~km}$ south of Lisbon. In Faro, the typical weeks considered were, in the summer, from August 14th to 20th and, in the winter, from January 1st to 7 th. For the reference case a TSR value of $60 \%$ was considered also taking into account the typical colors of the buildings and the Portuguese legislation [9] An emissivity of 0.90 was assumed for the external walls. A roof made of clay tile was also assumed for Faro with $40 \%$ of TSR and 0.90 of emissivity.

Table 12 presents values of $\mathrm{T}_{\max }$, over the typical summer week. Since Faro has high solar radiation levels, a great impact on using cool paints was observed; a $\mathrm{T}_{\max }$ reduction between $1.3{ }^{\circ} \mathrm{C}$ and $4.6^{\circ} \mathrm{C}$ was noted. The thermal insulation made the maximum $\mathrm{T}_{\max }$ to rise of up to $2.1^{\circ} \mathrm{C}$ compared with the reference case.

The results of $\mathrm{T}_{\text {min }}$ obtained over the typical winter week of Faro are presented in Table 13. Also at this location, cool paints originated a non-desirable $T_{\min }$ reduction between $0.4{ }^{\circ} \mathrm{C}$ and $1.1^{\circ} \mathrm{C}$, while using thermal insulation originated a positive impact in $\mathrm{T}_{\min }$ that increased up to $2.9^{\circ} \mathrm{C}$.

Table 14 shows the annual energy demand of buildings located in Faro. Cool paints always originated a reduction of the annual cooling demand and a maximum increase

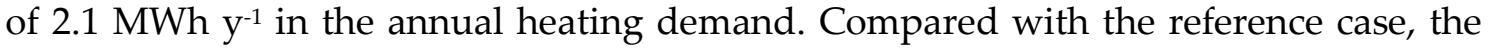
global impact of using cool paints represented a maximum reduction of $0.5 \mathrm{MWh} \mathrm{y}^{-1}$ in the annual energy demand. Table 14 shows that thermal insulation originated a

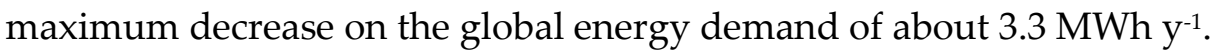

Soil thermal inertia is noticed in the results shown in Tables 6, 7, 9, 10, 12 and 13, where the ground floor temperature is either lower or higher than that of the first floor during the summer or winter time, respectively.

Table 12. $\mathrm{T}_{\max }$ Over the typical summer week of Faro. 


\begin{tabular}{|c|c|c|c|c|c|c|}
\hline Building & Case & Temperature $/{ }^{\circ} \mathrm{C}$ & $\begin{array}{l}\text { Ground } \\
\text { floor }\end{array}$ & $\begin{array}{l}\text { First } \\
\text { floor }\end{array}$ & $\begin{array}{l}\text { Second } \\
\text { floor }\end{array}$ & Exterior \\
\hline \multirow[t]{5}{*}{ BD1 } & Reference & $T_{\max }$ & 27.6 & 28.7 & 29.2 & 29.5 \\
\hline & Cool paints & $T_{\max }$ & 25.4 & 25.8 & 24.8 & \\
\hline & (BD1-CP) & $\Delta T_{\max }$ & -2.2 & -2.9 & -4.4 & - \\
\hline & Insulation & $T_{\max }$ & 28.1 & 30.0 & 29.7 & 29.5 \\
\hline & (BD1-TI) & $\Delta T_{\max }$ & +0.5 & +1.3 & +0.5 & - \\
\hline \multirow[t]{5}{*}{ BD2 } & Reference & $T_{\max }$ & 27.7 & 29.0 & 29.5 & 29.5 \\
\hline & Cool paints & $T_{\max }$ & 25.7 & 26.5 & 24.9 & \\
\hline & (BD2-CP) & $\Delta T_{\max }$ & -2.0 & -2.5 & -4.6 & - \\
\hline & Insulation & $T_{\max }$ & 28.2 & 31.1 & 30.6 & 29.5 \\
\hline & (BD2-TI) & $\Delta T_{\max }$ & +0.5 & +2.1 & +1.1 & - \\
\hline \multirow[t]{3}{*}{ BD3 } & Reference & $T_{\max }$ & 28.8 & 30.8 & 30.5 & 29.5 \\
\hline & Cool paints & $T_{\max }$ & 27.5 & 29.0 & 27.5 & \\
\hline & (BD3-CP) & $\Delta T_{\max }$ & -1.3 & -1.8 & -3.0 & - \\
\hline
\end{tabular}

Table 13. $\mathrm{T}_{\min }$ over the typical winter week of Faro.

\begin{tabular}{|c|c|c|c|c|c|c|}
\hline Building & Case & Temperature $/{ }^{\circ} \mathrm{C}$ & $\begin{array}{l}\text { Ground } \\
\text { floor }\end{array}$ & $\begin{array}{l}\text { First } \\
\text { floor }\end{array}$ & $\begin{array}{l}\text { Second } \\
\text { floor }\end{array}$ & Exterior \\
\hline \multirow[t]{5}{*}{ BD1 } & Reference & $T_{\min }$ & 12.2 & 12.9 & 11.9 & 8.1 \\
\hline & Cool paints & $T_{\min }$ & 11.6 & 12.0 & 11.2 & \\
\hline & (BD1-CP) & $\Delta T_{\min }$ & -0.6 & -0.9 & -0.7 & - \\
\hline & Insulation & $T_{\min }$ & 13.1 & 14.4 & 14.0 & 8.1 \\
\hline & (BD1-TI) & $\Delta T_{\min }$ & +0.9 & +1.5 & +2.1 & - \\
\hline \multirow[t]{5}{*}{ BD2 } & Reference & $T_{\min }$ & 12.8 & 13.8 & 12.3 & 8.1 \\
\hline & Cool paints & $T_{\min }$ & 12.1 & 12.7 & 11.5 & \\
\hline & (BD2-CP) & $\Delta T_{\min }$ & -0.7 & -1.1 & -0.8 & - \\
\hline & Insulation & $T_{\min }$ & 13.7 & 15.6 & 15.2 & 8.1 \\
\hline & (BD2-TI) & $\Delta T_{\min }$ & +0.9 & +1.8 & +2.9 & - \\
\hline \multirow[t]{3}{*}{ BD3 } & Reference & $T_{\min }$ & 14.0 & 15.3 & 14.9 & 8.1 \\
\hline & Cool paints & $T_{\min }$ & 13.6 & 14.5 & 14.2 & \\
\hline & (BD3-CP) & $\Delta T_{\min }$ & -0.4 & -0.8 & -0.7 & - \\
\hline
\end{tabular}

Table 14. Annual energy demand for studied cases, located in Faro.

\begin{tabular}{lllll}
\hline Building & Case & \multicolumn{3}{l}{ Energy demand/MWh $\mathrm{y}^{-1}$} \\
\cline { 3 - 5 } & & Cooling & Heating & Total \\
\hline BD1 & Reference & 2.8 & 5.6 & 8.4 \\
& Cool paints (BD1-CP) & 0.9 & 7.7 & 8.6 \\
& Insulation (BD1-TI) & 2.2 & 2.9 & 5.1 \\
BD2 & Reference & 2.8 & 4.3 & 7.1 \\
& Cool paints (BD2-CP) & 0.9 & 5.9 & 6.8 \\
& Insulation (BD2-TI) & 2.5 & 2.0 & 4.5 \\
BD3 & Reference & 2.5 & 2.0 & 4.5 \\
& Cool paints (BD3-CP) & 1.4 & 2.6 & 4.0 \\
\hline
\end{tabular}

3.4. Thermal comfort analysis during specific real weather periods

Since the climate file uses typical averaged weather data, especially hot or cold weeks are not considered, although in reality they occur. These outlier conditions significantly influence the decision of house-owners in terms of deciding for one or another thermal 
comfort solution.

\subsubsection{Porto, Portugal}

Fig. 5 presents two real hot periods in Porto, from July 4th to 7th of 2010 and from September 2nd to 6th of 2012. Data shows daily maximum values of global solar radiation of about $1000 \mathrm{~W} \mathrm{~m}^{-2}$ and maximum temperatures overpassing $30{ }^{\circ} \mathrm{C}$.

Simulations considering the building with a single wall façade (BD1) were performed and the indoor temperature difference be-tween the reference case (BD1) and, the reference case with thermal insulation (BD1-TI) and the reference case coated with cool paints (BD1-CP) were calculated. The average of these temperature differences, $\Delta \mathrm{T}_{\text {average, }}$ for each period of time are shown in Tables 15 and 16.

For the first period (July 4th to 7th), BD1-TI showed the greatest indoor temperature reduction compared with the reference case. However, it should be emphasized that on the second floor, BD1-CP showed the highest temperature reduction, $4.2{ }^{\circ} \mathrm{C}$.

Interestingly, the opposite is observed in the second period (September 2nd to 6th): the greatest indoor temperature reductions were always obtained with BD1-CP. To understand these results it is necessary to note that the first period of time is close to the summer solstice, when the sun reaches $71^{\circ}$ of maximum altitude, and the second period happens when the sun reaches $55^{\circ}$ of maximum altitude. Since for the second period the sun strikes more strongly on the house's walls, the use of cool paints originates higher temperature reductions.

\subsubsection{Bragança, Portugal}

Bragança is a city in north-eastern Portugal (41 $\left.45^{\prime} \mathrm{N} 6^{\circ} 44^{\prime} \mathrm{W}\right)$, located $255 \mathrm{~km}$ northeast of Porto and $515 \mathrm{~km}$ from Lisbon, in a plateau at ca. $700 \mathrm{~m}$ high. Bragança receives especially high solar irradiance and the exterior temperature is not especially hot. These are the best conditions for cool paints to prove their value on the thermal comfort of buildings. It was selected the period from August 2nd to 8th of 2004 e Fig. 6.

Table 17 shows the temperature differences, $\Delta \mathrm{T}_{\text {average, }}$ for this period of time. One can see

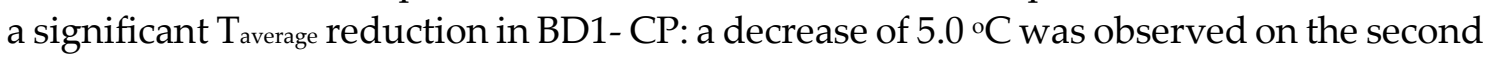
floor. On the other hand, in BD1-TI a reduction of $0.9{ }^{\circ} \mathrm{C}$ was observed on the ground floor, a null impact was noted on the first floor, while a Taverage increase of $0.6{ }^{\circ} \mathrm{C}$ was assessed on the second floor.

Table 15. $\Delta \mathrm{T}_{\text {average }}$ for the period of July $4^{\text {th }}$ to $7^{\text {th }}$ of 2010.

\begin{tabular}{llrrrl}
\hline Case & Temperature $/{ }^{\circ} \mathrm{C}$ & $\begin{array}{l}\text { Ground } \\
\text { floor }\end{array}$ & $\begin{array}{l}\text { First } \\
\text { floor }\end{array}$ & $\begin{array}{l}\text { Second } \\
\text { floor }\end{array}$ & Exterior \\
\hline Reference BD1 & $T_{\text {average }}$ & 27.9 & 30.1 & 32.6 & 28.9 \\
Cool paints & $T_{\text {average }}$ & 26.1 & 27.9 & 28.4 & \\
(BD1-CP) & $\boldsymbol{\Delta T}_{\text {average }}$ & $-\mathbf{1 . 8}$ & -2.2 & -4.2 & - \\
Insulation & $T_{\text {average }}$ & 24.9 & 26.6 & 29.0 & 28.9 \\
(BD1-TI) & $\boldsymbol{S T}_{\text {average }}$ & $-\mathbf{3 . 0}$ & -3.5 & -3.6 & - \\
\hline
\end{tabular}

Table 16. $\Delta \mathrm{T}_{\text {average }}$ for the period of September $2^{\text {nd }}$ to $6^{\text {th }}$ of 2012. 


\begin{tabular}{llcrll}
\hline Case & Temperature $/{ }^{\circ} \mathrm{C}$ & $\begin{array}{l}\text { Ground } \\
\text { floor }\end{array}$ & $\begin{array}{l}\text { First } \\
\text { floor }\end{array}$ & $\begin{array}{l}\text { Second } \\
\text { floor }\end{array}$ & Exterior \\
\hline Reference BD1 & $T_{\text {average }}$ & 25.7 & 27.1 & 27.5 & 25.7 \\
Cool paints & $T_{\text {average }}$ & 24.1 & 25.0 & 24.5 & \\
(BD1-CP) & $\boldsymbol{\Delta T}_{\text {average }}$ & $-\mathbf{1 . 6}$ & $-\mathbf{2 . 1}$ & $\mathbf{- 3 . 0}$ & - \\
Insulation & $T_{\text {average }}$ & 24.6 & 26.3 & 27.5 & 25.7 \\
(BD1-TI) & $\mathbf{S T}_{\text {average }}$ & $\mathbf{- 1 . 1}$ & $\mathbf{- 0 . 8}$ & $\approx \mathbf{0}$ & - \\
\hline
\end{tabular}
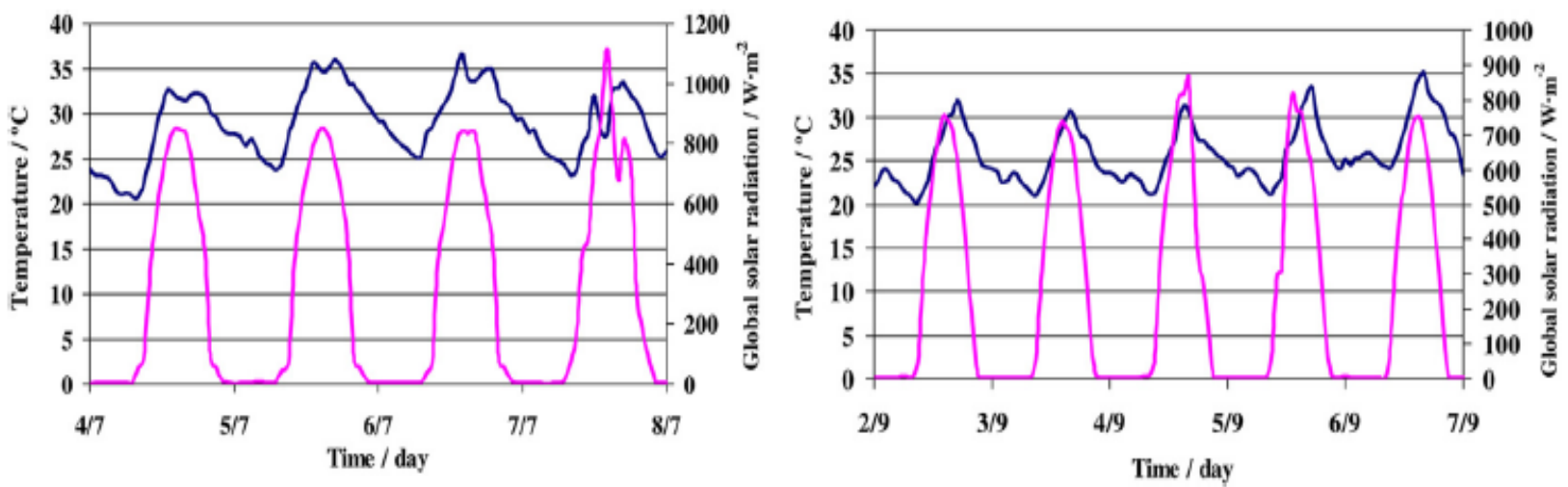

Fig. 5. Exterior air temperature and global solar radiation histories: a) from July $4^{\text {th }}$ to $7^{\text {th }}$ of 2010 and b) from September $2^{\text {nd }}$ to $6^{\text {th }}$ of 2012.

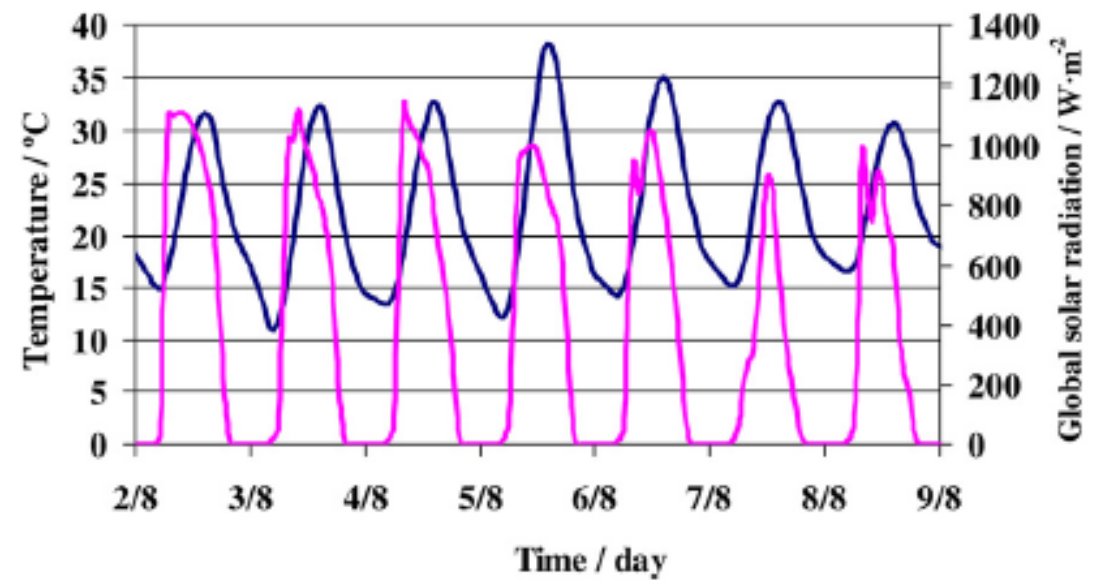

Fig. 6. Exterior air temperature and global solar radiation histories from August $2^{\text {nd }}$ to $8^{\text {th }}$ of 2004.

Table 17. $\Delta \mathrm{T}_{\text {average }}$ for the period of August $2^{\text {nd }}$ to $8^{\text {th }}$ of 2004 . 


\begin{tabular}{llcccl}
\hline Case & Temperature $/{ }^{\circ} \mathrm{C}$ & $\begin{array}{l}\text { Ground } \\
\text { floor }\end{array}$ & $\begin{array}{l}\text { First } \\
\text { floor }\end{array}$ & $\begin{array}{l}\text { Second } \\
\text { floor }\end{array}$ & Exterior \\
\hline Reference BD1 & $T_{\text {average }}$ & 25.8 & 27.7 & 28.0 & 22.4 \\
Cool paints & $T_{\text {average }}$ & 23.0 & 23.9 & 23.0 & \\
(BD1-CP) & $\boldsymbol{\Delta T}_{\text {average }}$ & -2.8 & $-\mathbf{3 . 8}$ & $\mathbf{- 5 . 0}$ & - \\
Insulation & $T_{\text {average }}$ & 24.9 & 27.6 & 28.6 & 22.4 \\
(BD1-TI) & $\mathbf{S T}_{\text {average }}$ & $\mathbf{- 0 . 9}$ & $\mathbf{- 0 . 1}$ & $\mathbf{+ 0 . 6}$ & - \\
\hline
\end{tabular}

\section{Conclusions}

The thermal and energy performances of a residential building were simulated using the dynamic simulator ESP-r, assessing the impact of using cool paints and/or thermal insulation. Buildings with different thermal characteristics, representing both old and new constructions, were assessed.

In Portugal, although the use of cool paints can lead to null annual cooling demand, the annual heating demand penalization was ca. 30\% compared with the reference cases (building of a given type not incorporating cool paints nor additional insulation). On the other hand, the use of thermal insulation in buildings BD1 and BD2, which is presently mandatory according to the Portuguese legislation, originated a null impact or a decrease on the cooling needs and saved on average ca. $43 \%$ of the heating needs compared to the reference case.

The analysis of two specific hot periods of real summer weather data of Porto, showed that the maximum altitude of the sun is critical as to which cool paint or thermal insulation solutions originate the highest temperature reduction; it was also concluded that for lower sun altitudes the cool paints performed better. For the selected real summer periods it was concluded that the cool paints play a critical role in controlling the high temperatures especially compared to the use of thermal insulation. The role of the cool paints is enhanced in locations that have high values of global solar radiation and high exterior temperatures. These conditions are especially observed in Bragança, a northeaster city in Portugal located at ca. $700 \mathrm{~m}$ of altitude. For this city, the role of the cool paints during an especially hot summer period is really dramatic and a maximum reduction of $5{ }^{\circ} \mathrm{C}$ was observed, from $28.0{ }^{\circ} \mathrm{C}$ to $23.0^{\circ} \mathrm{C}$, which is an acceptable indoor temperature.

It was concluded that cool paints are the best approach to minimize the impact of the hottest days of the year in regions with similar weather as Portugal $\left(40^{\circ} \mathrm{N}\right)$ and a cheap thermal comfort controlling solution, especially concerning upgrading existing buildings. However, the use of thermal insulation showed to be preferable in terms of energy savings, when both heating and cooling seasons are considered simultaneously, while the most effective solution was using both in conjunction.

\section{Acknowledgements}

The authors acknowledge the Portuguese Foundation for Science and Technology (FCT) and CIN, S.A. for the financial support of Diana Dias's Ph.D. grant (SFRH/BDE/33548/2009). The authors would also like to acknowledge the technical support of LEPAE, IDMEC and ARCP (www.arcp.pt).

\section{References}


[1] Portuguese Meteorological Institute, Heat Wave, Ministry of Education and Science, www.ipma.pt/pt/educativa/tempo.clima/index.jsp?page1/4clima.onda. calor.xml (accessed on 21.08.13) (in Portuguese).

[2] G.A. Meehl, C. Tebaldi, More intense, more frequent, and longer lasting heat waves in the 21st century, Science 305 (2004) 994-997.

[3] report number: 978-92-9167-980-5, Energy and Environment Report 2008, European Environment Agency, Copenhagen, Denmark, 2008, http://

dx. doi.org/10.2800/10548.

[4] Directorate General for Energy and Geology, Residential Energy Consumption Survey 2010 (Inquérito ao Consumo de Energia no Sector Doméstico 2010), Statistics Portugal, Lisbon, Portugal, 2011 (in Portuguese).

[5] European Parliament and of the Council, Directive 2010/31/EU e Energy Performance of Buildings, Official Journal of the European Communities, 2010.

[6] European Parliament and of the Council, Directive 2002/91/EC on the Energy Performance of Buildings, Official Journal of the European Communities, 2002.

[7] Ministry of the Economy and Innovation, Decree-Law No 78/2006 of April 4 e National System of Energy Certification and Indoor Air Quality of Buildings (Sistema Nacional de Certificação Energética e da Qualidade do Ar Interior nos Edifícios), Official Gazette (Diário da República e I Série e A), 2006 (in Portuguese).

[8] Ministry of Public Works Transport and Communications, Decree-Law No 79/2006 of April 4 e Regulation for Energetic Systems related to Building Cli-matization (Regulamento dos Sistemas Energéticos de Climatização em Edi-fícios), Official Gazette (Diário da República e I Série e A), 2006 (in Portuguese).

[9] Ministry of Public Works Transport and Communications, Decree-Law No 80/2006 of April 4 e Regulation on Thermal Insulation in Buildings (Regulamento das Características de Comportamento Térmico dos Edifí-cios), Official Gazette (Diário da República e ISérie e A), 2006 (in Portuguese).

[10] M.A. Lind, R.B. Pettit, K.D. Masterson, The sensitivity of solar transmittance, reflectance and absorptance to selected averaging procedures and solar irra-diance distributions, J. Sol. Energy Eng. 102 (1980) 34-40.

[11] American Society for Testing and Materials, ASTM G173-03: Standard Tables for Reference Solar Spectral Irradiances: Direct Normal and Hemi-spherical on 37๑ Tilted Surfaces, 2008.

[12] P. Kubelka, F. Munk, An article on optics of paint layers, Z. Tech. Phys. 12 (1931) 593-601.

[13] P. Kubelka, New contributions to the optics of intensely light-scattering ma-terials. Part I, J. Opt. Soc. Am. 38 (1947) 448-457.

[14] H. Akbari, Measured energy savings from the application of reflective roofs in two small non-residential buildings, Energy 28 (2003) 953-967.

[15] R. Levinson, P. Berdahl, H. Akbari, Solar spectral optical properties of pigments e part II: survey of common colorants, Sol. Energy Mater. Sol. Cells 89 (2005) 351-389.

[16] Lawrence Berkeley National Laboratory, Pigment Database, coolcolors.lbl.gov/LBNL-Pigment-Database/database.html (accessed 31.10.12).

[17] R. Levinson, P. Berdahl, A.A. Berhe, H. Akbari, Effects of soiling and cleaning on the reflectance and solar heat gain of a light-colored roofing membrane, Atmos. Environ. 39 (2005) 7807-7824. 
[18] P. Berdahl, H. Akbari, R. Levinson, J. Jacobs, F. Klink, R. Everman, Three-year weathering tests on asphalt shingles: solar reflectance, Sol. Energy Mater. Sol. Cells 99 (2012) 277-281.

[19] R. Levinson, P. Berdahl, H. Akbari, W. Miller, I. Joedicke, J. Reilly, Y. Suzuki, M. Vondran, Methods of creating solar-reflective nonwhite surfaces and their application to residential roofing materials, Sol. Energy Mater. Sol. Cells 91 (2007) 304314.

[20] R. Levinson, H. Akbari, P. Berdahl, K. Wood, W. Skilton, J. Petersheim, A novel technique for the production of cool colored concrete tile and asphalt shingle roofing products, Sol. Energy Mater. Sol. Cells 94 (2010) 946-954.

[21] M. Ichinose, T. Inoue, Y. Sakamoto, Long-term performance of high-reflectivity exterior panels, Build. Environ. 44 (2009) 1601-1608.

[22] C. Romeo, M. Zinzi, Impact of a cool roof application on the energy and comfort performance in an existing non-residential building. A Sicilian case study, Energy Build. (2011), http://dx.doi.org/10.1016/j.enbuild.2011.07.023.

[23] D.A. Luxmoore, M.T.R. Jayasinghe, M. Mahendran, Mitigating temperature increases in high lot density sub-tropical residential developments, Energy Build. 37 (2005) 1212-1224.

[24] X. Wang, C. Kendrick, R. Ogden, J. Maxted, Dynamic thermal simulation of a retail shed with solar reflective coatings, Appl. Therm. Eng. 28 (2008) 1066-1073.

[25] J. Han, L. Lu, H. Yang, Investigation on the thermal performance of different lightweight roofing structures and its effect on space cooling load, Appl. Therm. Eng. 29 (2009) 2491-2499.

[26] Energy Systems Research Unit, ESP-r e ESRU, www.esru.strath.ac.uk/Programs/ESP-r.htm, (accessed 30.09.12).

[27] J. Fong, Z. Alwan, Modelling to predict future energy performance of solar thermal cooling systems for building applications in the North East of England, Appl. Therm. Eng. 57 (2013) 81-89.

[28] Energy Systems Research Unit, The ESP-r Cookbook, www.esru.strath.ac.uk/Documents/ESP-r_cookbook_dec_2010.pdf (accessed 30.09.12).

[29] Energy Efficiency and Renewable Energy, EnergyPlus Energy Simulation Software e Weather Data, apps1.eere.energy.gov/buildings/energyplus/cfm/weather_data3.cfm/region $1 / 46$ _europe _wmo_region_6/country $1 / 4 \mathrm{PRT} /$

cname $1 / 4$ Portugal (accessed on 31.01.13).

[30] C.A.P. Santos, L. Matias, U-values/Building envelope elements (Coeficiente de Transmissão Térmica de Elementos da Envolvente dos Edifícios e Verão actualizada 2006), National Laboratory for Civil Engineering (Lab-oratório Nacional de Engenharia Civil), Lisbon, Portugal, 2006 (in Portuguese). 